\title{
Callogenesis and in vitro Regeneration of Baru (Dipteryx alata Vog.) Esprouts
}

\author{
Victória Maria Ingre Targa ${ }^{1}$, Francilina Araújo Costa ${ }^{1}$, Josimara Nolasco Rondon ${ }^{2} \&$ Wagner Campos Otoni ${ }^{3}$ \\ ${ }^{1}$ Catolic University Dom Bosco, Campo Grande, MS, Brazil \\ ${ }^{2}$ Federal University of Mato Grosso do Sul, Campo Grande, MS, Brazil \\ ${ }^{3}$ Federal University of Viçosa, Minas Gerais, Brazil \\ Correspondence: Josimara Nolasco Rondon, Federal University of Mato Grosso do Sul, Campo Grande, MS, \\ Brazil. E-mail: rondon.josimara@yahoo.com.br
}

Received: November 25, 2020

doi:10.5539/jas.v13n4p128
Accepted: March 2, $2021 \quad$ Online Published: March 15, 2021

URL: https://doi.org/10.5539/jas.v13n4p128

\begin{abstract}
The aim of this study was to evaluate the effect of different concentrations of 6-benzylaminopurine (BAP) and naphthalene acetic acid (ANA) on calogenesis and regeneration from baru leaf and apex segments. The explants were obtained from baru plants previously established in vitro from almonds and cauline apices. The leaf segments were placed in Petri dishes containing MS medium (Murashige \& Skoog, 1962) with concentrations $\left(0.0,2.0,3.0,4.0\right.$ and $\left.5.0 \mathrm{mg} \mathrm{L}^{-1}\right)$ BAP combined with ANA $\left(0.0\right.$ and $\left.2.0 \mathrm{mg} \mathrm{L}^{-1}\right)$. The shoot apices were inoculated in test tubes with the same medium using the concentrations $\left(0.0,0.5,1.0\right.$ and $\left.1.5 \mathrm{mg} \mathrm{L}^{-1}\right) \mathrm{BAP}$ combined $\left(0.0\right.$ and $\left.0.1 \mathrm{mg} \mathrm{L}^{-1}\right)$ ANA. After 25 days of inoculation, the percentages of callus and texture in leaf explants and apices were evaluated. The number of shoots was also evaluated by the Scott-Knott test at 5\% of probability. The most efficient concentration in the formation of callus in leaves was $3.0 \mathrm{mg} \mathrm{L}^{-1} \mathrm{BAP}+2.0 \mathrm{mg}$ $\mathrm{L}^{-1}$ ANA (68.88\%), at apexes the most efficient concentration was $1.0 \mathrm{mg} \mathrm{L}^{-1}$ BAP without ANA with $100 \%$ calogenesis. The most effective concentration was $1.0 \mathrm{mg} \mathrm{L}^{-1}$ BAP without ANA with an average of 1.90 of shoots in relation to the concentrations evaluated.
\end{abstract}

Keywords: phytoregulators, baru, callus, leaf explants, Dipteryx alata

\section{Introduction}

Cerrado is one of the main Biomas of Brazil, both in area and in biodiversity (Ribeiro \& Walter, 2008). Native to this biome, the barueiro (Dipteryx alata Vog.) is an economically promising species with multiple uses, such as the exploitation of wood, fruits and seeds (Ratter et al., 2000; Durigan et al., 2011). It is a fruitful arboreal, highly valued for its economic potential, with various possibilities for use in food, forage, forestry, silvopastoral system, landscape and reforestation of degraded areas (Larson, 2014).

Baru has been studied due to lipid and protein properties, as well as the production of bioactive molecules used in the food and pharmaceutical industry. The baru fruit also serves for human consumption, both pulp and baru almond can be used in human nutrition, and the pulp consists mainly of carbohydrates (63\%), predominantly starch, insoluble fibers and sugars (Alves et al., 2010). Almond is consumed in nature or toast, has high lipid levels $(42 \%)$, protein $(30 \%)$, calcium, phosphorus, manganese and potassium, in addition to iron, zinc, selenium and considerable carbohydrate and fibre level (Souza et al., 2011).

Few reports regarding the micropropagation of Dipteryx alata as seed germination in vitro, but with inconclusive results (Mamedes \& Araújo, 2010). The germination rate of seeds is high, however, the fruits can present seeds with pathogens that will give rise to unhealthy seedlings, since their fruits can remain for a long period in the field. For the purpose of obtaining pathogen-free seedlings, plant tissue culture has been used (Perez, 2004).

Plant tissue cultivation techniques have been effectively used for the clonal propagation and genetic improvement of different crops (Rocha et al., 2012; Sousa et al., 2019), providing higher productive and pathogen-resistant plants, higher vigour and adaptability at environments heterogeneous. Cultivation in vitro is an important strategy to solve problems crop using classical genetic improvement and wood biotechnology (Erigs \& Schuch, 2005). 
Zygotic embryos culture is a very common procedure to regenerate seed embryos that do not germinate under conventional sowing conditions. However, its greatest applicability is through the rescue of immature embryos from developing seeds (Raghavan, 2003).

In vitro embryo cultivation is a promising technique for advancing knowledge about certain species, because, based on such activity, is possible reproduction and embryonic development, dormancy breakdown and plant production (Raghavan, 2003).

Calogenesis is the methodologie more applied to cultivation in vitro, also used for production of secondary metabolites and genetic transformation (Santos, 2004). Studies with callus can also serve as initial point for determining necessary conditions of development (Landa et al., 2000). For induction of callus, virtually any part of the plant can be used as an explant. However, it is sought to use those who contain the highest proportion of meristematic tissues or who have the greatest ability to express totipotence where each plant cell had the genetic potential to regenerate a plant (Flores, 2006).

In regeneration of woody plants, usually leaves and internodes developed in vitro are explants more used (Pérez-Tornero et al., 2000; Cassana et al., 2007). Significant differences in organogenic capacity in vitro are found when varying the type of explant and the nutritional composition of the culture medium. However, most components optimised in the growth medium are the phytoregulators, particularly auxin/cytokinin balance (Erig $\&$ Schuch, 2005).

Auxins act in cell division and tissue expansion, while cytokinins are used regularly to stimulate multiple sprouts (auxins and cytokinins act as growth regulators, presenting an important work in vitro, cell division and tissue expansion), while cytokinins are regularly used to stimulate multiple sprouts (Morais, 2012).

Among the growth regulators used to induce callus, 2,4-D (2,4 dichlorophenoxyacetic), ANA (1-naphthalene acetic acid), BAP (6-benzylaminopurine) and TDZ (thidiazuron) are the most important. Callus is also obtained in the interaction between auxins and cytokinins.

The physiological effect of each regulator depends on its concentration in the medium, and each part of the plant has a different response to changes in the concentrations of auxins and cytokinins (Pozo et al., 2005). BAP is a cytokinin added to right concentrations to the culture medium and promotes increase in the number buds, leaves and sprouts and increase the production of fresh mass and quality of cultivated plants. ANA is auxin that inhibit the proliferation of sprouts, however, it is widely used in association with BAP, because the interaction between both it can further favor the quality of micropropagated plants (Torres et al., 1998).

Therefore, studies aiming at the regeneration of baru plants in vitro, formation of corns, production of multiple shoots aiming at the production of seedlings micropropagated and studies of the production of secondary metabolites may be used by pharmaceutical industry for extracting the active ingredient.

In view of the lack of specific information regarding the in vitro propagation of baru, the study aims to evaluate the effect of different concentrations of 6-benzylaminopurine (BAP) and naphthalene acetic acid (ANA), and their combinations, in callogenesis and plant regeneration from leaf segments and stem apex of baru in vitro.

\section{Materials and Methods}

Baru fruits were collected between August and September 2018 in the Campo Grande city, MS.

These fruits were stored at room temperature at the school farm of Catolic University Dom Bosco, Campo Grande, MS.

The seeds were removed from fruits with a hydraulic press, selecting the major size, and the plants in vitro were used to remove the leaf segments.

\subsection{Callogenesis Procedure From Leaf Segments}

Leaves segments $\left(1 \mathrm{~cm}^{2}\right)$ were placed in Petri dishes containing $30 \mathrm{ml}$ of MS culture medium (Murashige \& Skoog, 1962), supplemented with different concentrations of BAP and ANA (Table 1), totaling four treatments with 10 repetitions. Each plot consisted of a Petri dish containing three explants. 
Table 1. Treatments used to induce callogenesis from leaf explants baru (Dipteryx alata Vog.)

\begin{tabular}{ll}
\hline Treatments & BAP and ANA concentrations \\
\hline $\mathrm{T}_{1}$ & $0.0 \mathrm{mg} \mathrm{L}^{-1} \mathrm{BAP}$ and $0.0 \mathrm{mg} \mathrm{L}^{-1} \mathrm{ANA}$ \\
$\mathrm{T}_{2}$ & $2.0 \mathrm{mg} \mathrm{L}^{-1} \mathrm{BAP}$ and $2.0 \mathrm{mg} \mathrm{L}^{-1} \mathrm{ANA}$ \\
$\mathrm{T}_{3}$ & $3.0 \mathrm{mg} \mathrm{L}^{-1} \mathrm{BAP}$ and $2.0 \mathrm{mg} \mathrm{L}^{-1} \mathrm{ANA}$ \\
$\mathrm{T}_{4}$ & $4.0 \mathrm{mg} \mathrm{L}^{-1} \mathrm{BAP}$ and $2.0 \mathrm{mg} \mathrm{L}^{-1} \mathrm{ANA}$ \\
$\mathrm{T}_{5}$ & $5.0 \mathrm{mg} \mathrm{L}^{-1} \mathrm{BAP}$ and $2.0 \mathrm{mg} \mathrm{L}^{-1} \mathrm{ANA}$ \\
\hline
\end{tabular}

The MS medium was enriched with $30.0 \mathrm{~g} \mathrm{~L}^{-1}$ sucrose and $7.0 \mathrm{~g} \mathrm{~L}^{-1}$ agar and $\mathrm{pH}$ adjusted to 5.8. After inoculation, the material was subjected to seven days of darkness and subsequently transferred to photoperiod of 16 hours and temperature of $27 \pm 2{ }^{\circ} \mathrm{C}$ under irradiation of $36 \mu \mathrm{mol} \mathrm{of} \mathrm{m}^{-2} \mathrm{~s}^{-1}$.

After 25 days of inoculation with leaf explants, the average percentage of callus formation and texture was evaluated.

Regarding texture the callus were classified into four types: A) compact (tightly bound cells); B) semi-compact (moderately bound cells); C) friable (loosely bound cells); and D) without reaction.

The callus from leaf explants were transferred to test tubes to obtain regeneration.

Tubes contained $15 \mathrm{ml}$ of MS medium with $2.0 \mathrm{mg} \mathrm{L}^{-1}$ BAP combined with $0.5 \mathrm{mg} \mathrm{L}^{-1}$ ANA, totaling a treatment with 10 repetitions (each plot consisted of a test tube).

After inoculation, the material was subjected to seven days of darkness and subsequently transferred to photoperiod of 16 hours and temperature of $27 \pm 2{ }^{\circ} \mathrm{C}$ under irradiation of $36 \mu \mathrm{mol} \mathrm{m} \mathrm{m}^{-2} \mathrm{~s}^{-1}$.

\subsection{Stem Callogenesis From Apexes and Regeneration}

After disinfestation, the seeds remained embedded for 24 hours in Petri dishes containing sterile distilled water to facilitate the removal of the embryos. After the imbibition period, the embryos were removed with the aid of forceps and scalpel.

The embryos were distributed in tubes containing $110 \mathrm{ml}$ of MS culture medium (Murashige \& Skoog, 1962), 30 $\mathrm{g} \mathrm{L}^{-1}$ sucrose, $100 \mathrm{mg} \mathrm{L}^{-1}$ inositol and $7 \mathrm{~g} \mathrm{~L}^{-1}$ of agar with $\mathrm{pH}$ adjusted to $5.8 \pm 0.1$ For one month, the embryos were kept in growth room located in the tissue culture laboratory, under temperature conditions of $25 \pm 2{ }^{\circ} \mathrm{C}$ under 16 hour photoperiod and irradiation of $36 \mu \mathrm{mol} \mathrm{m}^{-2} \mathrm{~s}^{-1}$.

\subsection{Stem Regeneration From Apexes}

Seedlings germinated in vitro were used to evaluate the effect of phytoregulators on callus from stem apexes.

Stem tips containing approximately two leaves, after one month of inoculation were placed in test tubes containing $15 \mathrm{ml}$ of MS medium (Murashige \& Skoog, 1962), supplemented with different concentrations of 6-benzylaminopurine (BAP) and naphthalene acetic acid (ANA), (Table 2), totaling seven treatments and 8 repetitions, each experimental unit represented by one test tube, each tube containing one explant.

Table 2. Treatments used to induce callogenesis and stem regeneration from apexes of baru (Dipteryx alata Vog.)

\begin{tabular}{ll}
\hline Treatments & Concentrations BAP and ANA \\
\hline $\mathrm{T}_{1}$ & $0.0 \mathrm{mg} \mathrm{L}^{-1} \mathrm{BAP}$ and $0.0 \mathrm{mg} \mathrm{L}^{-1}$ ANA \\
$\mathrm{T}_{2}$ & $0.5 \mathrm{mg} \mathrm{L}^{-1} \mathrm{BAP}$ and $0,0 \mathrm{mg} \mathrm{L}^{-1}$ ANA \\
$\mathrm{T}_{3}$ & $0.5 \mathrm{mg} \mathrm{L}^{-1} \mathrm{BAP}$ and $0.1 \mathrm{mg} \mathrm{L}^{-1}$ ANA \\
$\mathrm{T}_{4}$ & $1.0 \mathrm{mg} \mathrm{L}^{-1} \mathrm{BAP}$ and $0.0 \mathrm{mg} \mathrm{L}^{-1}$ ANA \\
$\mathrm{T}_{5}$ & $1.0 \mathrm{mg} \mathrm{L}^{-1} \mathrm{BAP}$ and $0.1 \mathrm{mg} \mathrm{L}^{-1}$ ANA \\
$\mathrm{T}_{6}$ & $1.5 \mathrm{mg} \mathrm{L}^{-1} \mathrm{BAP}$ and $0.1 \mathrm{mg} \mathrm{L}^{-1}$ ANA \\
$\mathrm{T}_{7}$ & $1.5 \mathrm{mg} \mathrm{L}^{-1} \mathrm{BAP}$ and $0.0 \mathrm{mg} \mathrm{L}^{-1}$ ANA \\
\hline
\end{tabular}

After inoculation of stem tips, they were placed in the dark after 20 days of inoculation of stem tips in medium and evaluated in relation the percentage of callus formation and its texture and the average number of shoots.

Regarding texture, the callus were classified into four types: A) compact (tightly bound cells); B) semi-compact (moderately bound cells); C) friable (loosely bound cells); and D) without reaction. 
Average sprouts formed in Dipteryx alata Vog. after 20 days of cultivation in medium MS supplemented with different concentrations of phytoregulators BAP and ANA. Shooting averages were compared Scott-Knott test (1974) at $5 \%$ probability using the Sisvar ${ }^{\circledR}$ statistical program.

\section{Results and Discussion}

\subsection{Evaluation of Foliar Calogenesis in Segments and Callus Regeneration}

Callus can be obtained from fragment of tissues that have the capacity to differentiate into tissues, organs and even embryos (R. Paiva \& P. D. O. Paiva, 2001). This process occurs because plant tissues have a high degree of plasticity for cell differentiation (Ikeuchi et al., 2013).

Callus production started on seventh day of cultivation. Concentration $3.0 \mathrm{mg} \mathrm{L}^{-1} \mathrm{BAP}$ and $2.0 \mathrm{mg} \mathrm{L}^{-1}$ ANA, was the one that provided highest number of explants callogenic $(68.88 \%)$. Concentration $5.0 \mathrm{mg} \mathrm{L}^{-1}$ BAP and addition $2.0 \mathrm{mg} \mathrm{L}^{-1}$ ANA promoted $24.44 \%$ of callus (Table 3 ). Other treatments evaluated did not provide callus formation (Table 3).

Table 3. Percentage of callogenesis in different concentrations of BAP and ANA in the in vitro leaf segments

\begin{tabular}{ll}
\hline Concentrations BAP and ANA & Callogenesis (\%) \\
\hline $0.0 \mathrm{~m} \mathrm{~L} \mathrm{~L}^{-1}$ BAP and $0.0 \mathrm{mg} \mathrm{L}^{-1}$ ANA & $00.00 \%$ \\
$2.0 \mathrm{~m} \mathrm{~L}^{-1}$ BAP and $2.0 \mathrm{~m} \mathrm{~L}^{-1}$ ANA & $00.00 \%$ \\
$3.0 \mathrm{~m} \mathrm{~L} \mathrm{~L}^{-1}$ BAP and $2.0 \mathrm{~m} \mathrm{~L} \mathrm{~L}^{-1}$ ANA & $68.88 \%$ \\
$4.0 \mathrm{~m} \mathrm{~L}^{-1} \mathrm{BAP}$ and $2.0 \mathrm{~m} \mathrm{~L}^{-1}$ ANA & $00.00 \%$ \\
$5.0 \mathrm{~m} \mathrm{~L}^{-1} \mathrm{BAP}$ and $2.0 \mathrm{~m} \mathrm{~L}^{-1} \mathrm{ANA}$ & $24.44 \%$ \\
\hline
\end{tabular}

There was a positive interaction between cytokinin and auxin concentrations in the induction of callus from baru leaf explants. Similar results were observed by Landa et al. (2000), which induced callogenesis in leaf explants of pequizeiro (Caryocar brasiliense Camb.) at a concentration $2.0 \mathrm{mg} \mathrm{L}^{-1}$ ANA and $1.0 \mathrm{mg} \mathrm{L}^{-1}$ BAP, approximately $91 \%$ formations of callus were obtained.

There was a positive interaction between the concentrations of calogenesis in baru leaf explants (Dipteryx alata Vog.), Rezende et al. (2019) observed better results for callus formation when used $2.5 \mathrm{mg} \mathrm{L}^{-1}$ BAP combined with $2.0 \mathrm{mg} \mathrm{L}^{-1}$ ANA.

Positive influence of auxin and cytokinin combination was also verified in trials involving calogenesis in several coffee cultivars (Santos et al., 2000). Similarly, in studies of calogenesis in coffee testing different doses of 2.4-D and $2.0 \mathrm{mgL}^{-1}$ kinetin. Maciel (2001) also found greater formation of primary nodular callus with high concentrations of 2.4-D.

The auxins are indispensable for the formation of callus, since they are responsible to start cellular division and control cellular growth and stretching processes (Taiz \& Zeiger, 2004). Cytokines are also necessary for plant cell division with positive results in embryogenic callus induction (Pasqual, 2001), confirming callogenesis observed in this experiment was probably favored by the joint action of these phytoregulators.

Santos et al. (2015) used 2.4-D and BAP in calogenesis in P. carniconectivum leaf explants, and observed that the effects of 2.4-D and BAP were individually significant in callus induction. 2.4-D induced callus in $77.62 \%$ of the explants, while BAP represented $73 \%$ in callus inductions.

After fifteenth day of cultivation, it was also observed regarding the texture of the callus, and there was only formation of friable and compact callus. The texture of callus was dependent on the concentrations of BAP and ANA used. Higher percentage of friable callus occurred in concentrations of $3.0 \mathrm{mg} \mathrm{L}^{-1}$ BAP combined with 2.0 mg L ${ }^{-1}$ ANA, totaling $35.55 \%$ callus (Figure 1A, Table 4).

However, the highest percentage of compact callus was fifteenth day of cultivation, it was also observed regarding the texture of callus that there was only formation of friable and compact callus. The texture of callus was dependent on the concentrations of BAP and ANA used. Higher percentage of friable callus occurred in concentrations of $3.0 \mathrm{mg} \mathrm{L}^{-1}$ BAP combined with $2.0 \mathrm{mg} \mathrm{L}^{-1}$ ANA, totaling $35.55 \%$ callus (Figure 1A, Table 4). However, highest percentage of compact callus was observed in the same concentration of $3.0 \mathrm{mg} \mathrm{L}^{-1} \mathrm{BAP}$ and $2.0 \mathrm{mg} \mathrm{L}^{-1}$ ANA totaling $66.66 \%$ callus (Figure 1B, Table 4). In Tables 3 and 4, the concentration of $4.0 \mathrm{mg} \mathrm{L}-1$ BAP and $2.0 \mathrm{mg} \mathrm{L}-1$ ANA may have inhibited the induction or formation of primary callus. 


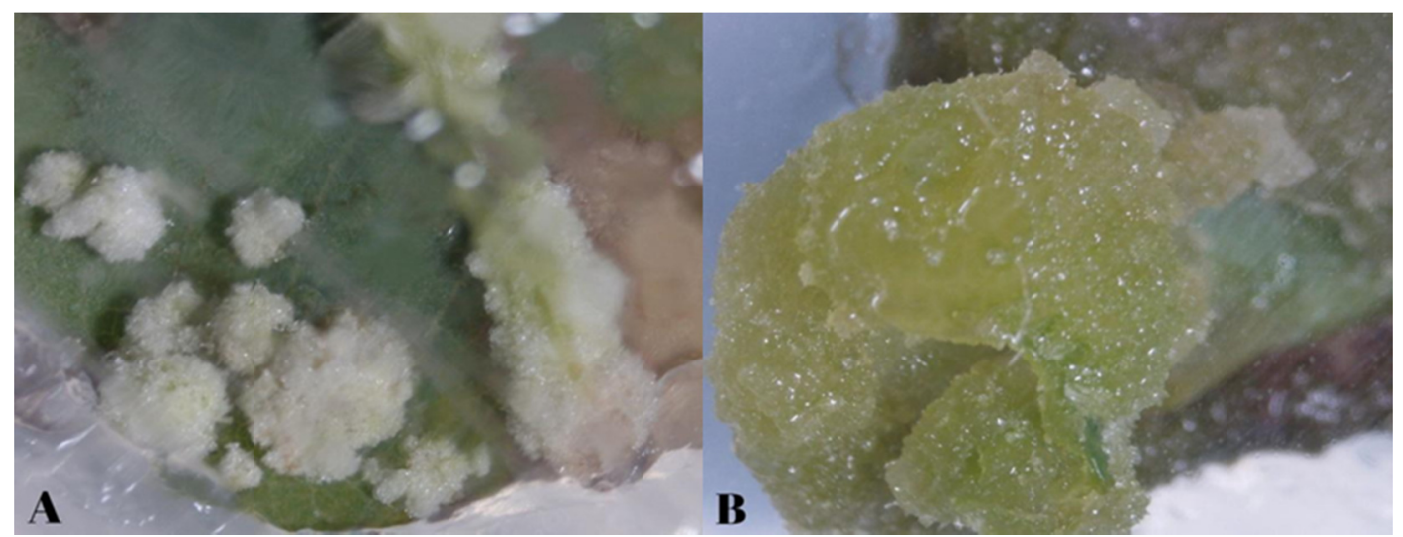

Figure 1. Formation of callus in vitro from Baru leaf segments on the thirteenth day of cultivation in MS medium. A: Friable callus; B: Compact callus

Table 4. Percentage of formation of friable and compact callus from in vitro Baru leaf segments

\begin{tabular}{lll}
\hline Concentrations BAP and ANA & Friable & Compact \\
\hline $0.0 \mathrm{~m} \mathrm{~L} \mathrm{~L}^{-1}$ BAP and $0.0 \mathrm{mg} \mathrm{L}^{-1}$ ANA & $00.00 \%$ & $00.00 \%$ \\
$2.0 \mathrm{mg} \mathrm{L}^{-1}$ BAP and $2.0 \mathrm{mg} \mathrm{L}^{-1}$ ANA & $00.00 \%$ & $00.00 \%$ \\
$3.0 \mathrm{~m} \mathrm{~L} \mathrm{~L}^{-1} \mathrm{BAP}$ and $2.0 \mathrm{mg} \mathrm{L}^{-1}$ ANA & $35.55 \%$ & $66.66 \%$ \\
$4.0 \mathrm{mg} \mathrm{L}^{-1}$ BAP and $2.0 \mathrm{mg} \mathrm{L}^{-1}$ ANA & $00.00 \%$ & $00.00 \%$ \\
$5.0 \mathrm{mg} \mathrm{L}^{-1}$ BAP and $2.0 \mathrm{mg} \mathrm{L}^{-1}$ ANA & $13.33 \%$ & $6.66 \%$ \\
\hline
\end{tabular}

Different results were obtained in nodal segments of Pfaffia tuberosa, where there is a greater proliferation of friable callus in the concentration of $1 \mathrm{mM} \mathrm{BAP}$ and $10 \mathrm{mM}$ 2.4-D in MS medium (Flores et al., 2006).

After formation of callus, both in compact and friable callus when they were transferred to the regeneration medium, no regeneration was observed; however, there was formation of more callus and later necrosis of these callus over time. Results different were observed by Dominguez et al. (2006), when the $2.0 \mathrm{mg} \mathrm{L}^{-1}$ concentration 2.4-D was used to obtain callus and subsequent regeneration from leaf explants of Piper auritum Kunth.

The treatments containing $1 \mathrm{mg} \mathrm{L}^{-1}$ BAP with and without addition of ANA and the treatment with $1.5 \mathrm{mg} \mathrm{L}^{-1}$ BAP plus $0.1 \mathrm{mg} \mathrm{L}^{-1}$ ANA provided $100 \%$ calogenesis, while the treatment where only concentration $1.5 \mathrm{mg} \mathrm{L}^{-1}$ BAP was added was lower (70\%). Other treatments obtained 80 to $90 \%$ callus (Table 5).

Table 5. Percentage of stem apexes with callus formation of Dipteryx alata Vog., after 20 days of culture in medium MS supplemented with different concentrations of BAP and ANA

\begin{tabular}{ll}
\hline Treatment & Calogenesis (\%) \\
\hline $0.0 \mathrm{mg} \mathrm{L}^{-1} \mathrm{BAP}$ and $0.0 \mathrm{mg} \mathrm{L}^{-1} \mathrm{ANA}$ & $0.0 \%$ \\
$0.5 \mathrm{mg} \mathrm{L}^{-1} \mathrm{BAP}$ and $0.0 \mathrm{mg} \mathrm{L}^{-1} \mathrm{ANA}$ & $80 \%$ \\
$0.5 \mathrm{mg} \mathrm{L}^{-1} \mathrm{BAP}$ and $0.1 \mathrm{mg} \mathrm{L}^{-1} \mathrm{ANA}$ & $90 \%$ \\
$1.0 \mathrm{mg} \mathrm{L}^{-1} \mathrm{BAP}$ and $0.0 \mathrm{mg} \mathrm{L}^{-1} \mathrm{ANA}$ & $100 \%$ \\
$1.0 \mathrm{mg} \mathrm{L}^{-1} \mathrm{BAP}$ and $0.1 \mathrm{mg} \mathrm{L}^{-1} \mathrm{ANA}$ & $100 \%$ \\
$1.5 \mathrm{mg} \mathrm{L}^{-1} \mathrm{BAP}$ and $0.1 \mathrm{mg} \mathrm{L}^{-1} \mathrm{ANA}$ & $100 \%$ \\
$1.5 \mathrm{mg} \mathrm{L}^{-1} \mathrm{BAP}$ and $0.0 \mathrm{mg} \mathrm{L}^{-1} \mathrm{ANA}$ & $70 \%$ \\
\hline
\end{tabular}

Callus induction is dependent on an intermediate hormonal balance of auxins, cytokines or both together (Nogueira, 2007). This supply of regulators in the culture medium was sufficient to balance the endogenous content of cytokines in the caulinar apex promoting callus formation.

There was no callus formation without addition of BAP and ANA (Table 2). The results obtained corroborate those of Cordeiro et al. (2004) that observed low calogenesis frequency in Schizolobium amazonicum (paricá) in culture medium without growth regulator. However, it is observed that concentration of the BAP regulator was 
used, with exception of the treatment $1.5 \mathrm{mg} \mathrm{L}^{-1}$ BAP combined with $0.1 \mathrm{mg} \mathrm{L}^{-1}$ ANA had a higher incidence of callus (Table 6).

Results found in this work are similar to those found by Machado et al. (2009), who worked with calogenesis induction in Ananas erectifolius (Curauá), where the phytoregulator thidiazuron, (group of cytokines) proved efficient inducer of calogenesis.

Formation of callus presented a predominant compact and friable texture, with coloration between green and yellow. Concentrations of 0.5 and $1 \mathrm{mg} \mathrm{L}^{-1}$ BAP combined with $0.1 \mathrm{mg} \mathrm{L}^{-1}$ ANA promoted highest number of callus compact $(90 \%)$ (Figure 2B). The highest number of callus friable $(100 \%)$ was obtained using $1.0 \mathrm{mg} \mathrm{L}^{-1}$ BAP and no addition of ANA (Figure 2A, Table 6). The formation of baru callus clusters started from the 20th day of cultivation. In this work we observed a higher occurrence of friable than compact callus. The release of cells, from friable callus, is faster than from compact callus, which favors the regeneration of new plants and the selection of variant biotypes in the improvement programs of species (Pescador et al.; 2000).

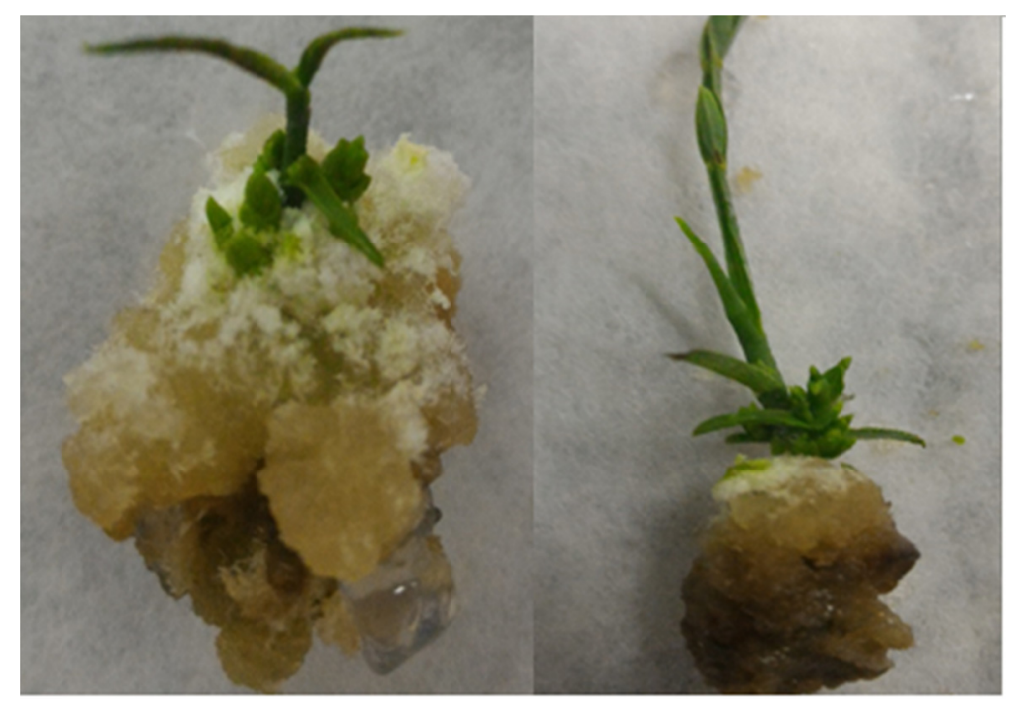

Figure 2. Dipteryx alata Vog. callus from stem apexes, after 20 days of in vitro cultivation.

Left: Friable callus; Right: Compact callus

Table 6. Percentage of friable and compact callus of Dipteryx alata Vog. from stem apexes with different dosages of BAP and ANA

\begin{tabular}{lll}
\hline Concentrations BAP and ANA & Friable (\%) & Compact (\%) \\
\hline $0.0 \mathrm{mg} \mathrm{L}^{-1}$ BAP and $0.0 \mathrm{mg} \mathrm{L}^{-1}$ ANA & $0 \%$ & $0 \%$ \\
$0.5 \mathrm{mg} \mathrm{L}^{-1} \mathrm{BAP}$ and $0.0 \mathrm{mg} \mathrm{L}^{-1}$ ANA & $60 \%$ & $20 \%$ \\
$0.5 \mathrm{mg} \mathrm{L}^{-1} \mathrm{BAP}$ and $0.1 \mathrm{mg} \mathrm{L}^{-1}$ ANA & $10 \%$ & $90 \%$ \\
$1.0 \mathrm{mg} \mathrm{L}^{-1} \mathrm{BAP}$ and $0.0 \mathrm{mg} \mathrm{L}^{-1}$ ANA & $100 \%$ & $0 \%$ \\
$1.0 \mathrm{mg} \mathrm{L}^{-1} \mathrm{BAP}$ and $0.1 \mathrm{mg} \mathrm{L}^{-1}$ ANA & $10 \%$ & $90 \%$ \\
$1.5 \mathrm{mg} \mathrm{L}^{-1} \mathrm{BAP}$ and $0.1 \mathrm{mg} \mathrm{L}^{-1} \mathrm{ANA}$ & $40 \%$ & $30 \%$ \\
$1.5 \mathrm{mg} \mathrm{L}^{-1} \mathrm{BAP}$ and $0.0 \mathrm{mg} \mathrm{L}^{-1} \mathrm{ANA}$ & $50 \%$ & $50 \%$ \\
\hline
\end{tabular}

Plant regeneration is through tissue culture, which is based on totipotency principle where each plant cell has genetic potential to regenerate a plant (Flores, 2006).

According to the results obtained, it was observed a difference in responses according to concentrations of BAP and ANA used in the number of shoots formed from callus originating from in vitro baru stem apexes (Table 7). The production of shoots started from the fifteenth day of cultivation (Figure 3). 


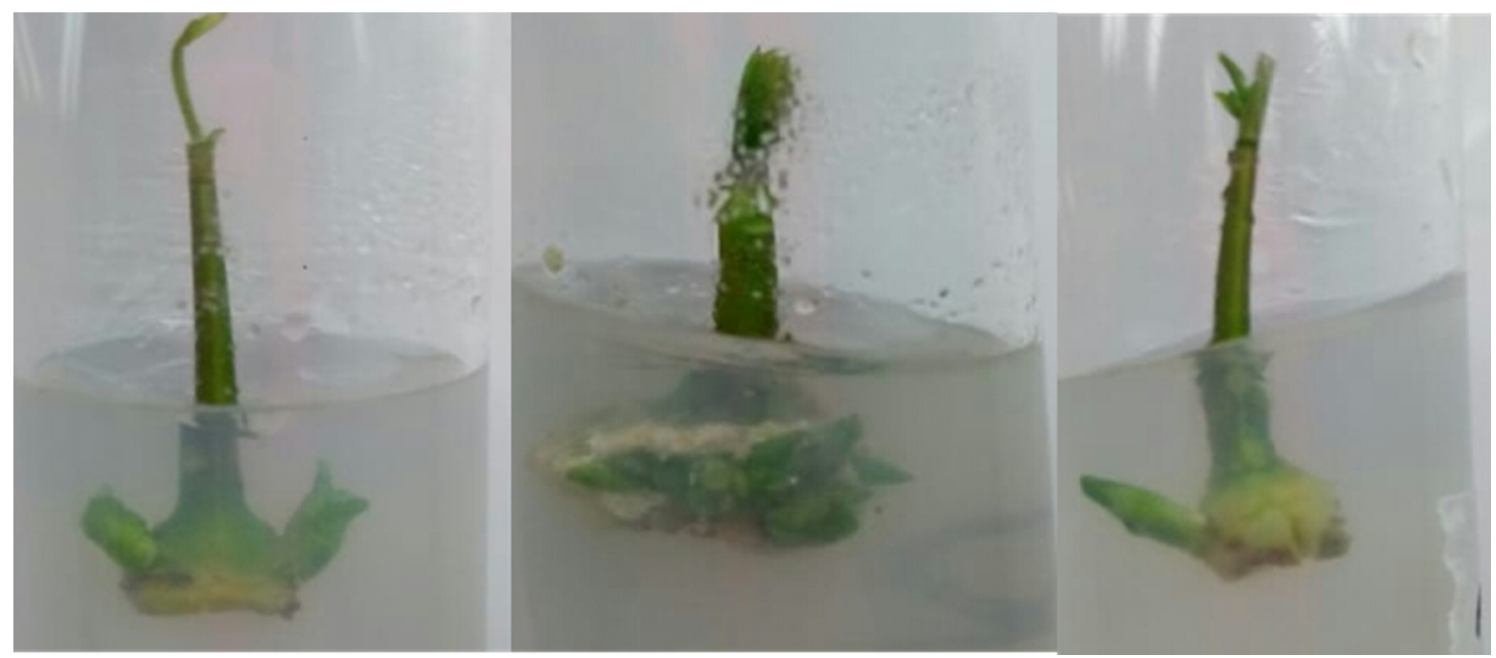

Figure 3. In vitro sprouting from stem apexes of baru after 20 days

According to the Table 7, higher numbers of sprouting were obtained in concentrations of 0.5 and $1 \mathrm{mg} \mathrm{L}^{-1} \mathrm{BAP}$ and no addition of ANA (Table 7). Treatments with $1.5 \mathrm{mg} \mathrm{L}^{-1} \mathrm{BAP}$ with and without $0.1 \mathrm{mg} \mathrm{L}^{-1}$ ANA there was no difference between these concentrations in the number of shoots formed (Table 7). Lower numbers of sprouts were observed in concentrations of 0.5 and $1 \mathrm{mg} \mathrm{L}^{-1}$ BAP combined with $0.1 \mathrm{mg} \mathrm{L}^{-1}$ ANA (Table 7).

Table 7. Average sprouts formed in Dipteryx alata Vog. after 20 days of cultivation in medium MS supplemented with different concentrations of phytoregulators BAP and ANA

\begin{tabular}{ll}
\hline Treatment & Shoots \\
\hline $0.0 \mathrm{mg} \mathrm{L}^{-1} \mathrm{BAP}$ and $0.0 \mathrm{mg} \mathrm{L}^{-1} \mathrm{ANA}$ & $1.00 \mathrm{c}$ \\
$0.5 \mathrm{mg} \mathrm{L}^{-1} \mathrm{BAP}$ and $0.0 \mathrm{mg} \mathrm{L}^{-1} \mathrm{ANA}$ & $1.83^{\mathrm{a}}$ \\
$0.5 \mathrm{mg} \mathrm{L}^{-1} \mathrm{BAP}$ and $0.1 \mathrm{mg} \mathrm{L}^{-1} \mathrm{ANA}$ & $1.00 \mathrm{c}$ \\
$1.0 \mathrm{mg} \mathrm{L}^{-1} \mathrm{BAP}$ and $0.0 \mathrm{mg} \mathrm{L}^{-1} \mathrm{ANA}$ & $1.90^{\mathrm{a}}$ \\
$1.0 \mathrm{mg} \mathrm{L}^{-1} \mathrm{BAP}$ and $0.1 \mathrm{mg} \mathrm{L}^{-1} \mathrm{ANA}$ & $1.10 \mathrm{c}$ \\
$1.5 \mathrm{mg} \mathrm{L}^{-1} \mathrm{BAP}$ and $0.1 \mathrm{mg} \mathrm{L}^{-1} \mathrm{ANA}$ & $1.54 \mathrm{~b}$ \\
$1.5 \mathrm{mg} \mathrm{L}^{-1} \mathrm{BAP}$ and $0.0 \mathrm{mg} \mathrm{L}^{-1} \mathrm{ANA}$ & $1.54 \mathrm{~b}$ \\
$\mathrm{CV}(\%)$ & 20.02
\end{tabular}

Note. Averages in the column followed by the same letter do not differ statistically at the $5 \%$ probability level by the Scott-Knott test.

Several studies indicate that cytokines are usually suppressed in the culture medium for formation of adventitious sprouts. While auxins are growth regulators that stimulate the formation of early roots in tissues predisposed to rooting (Santos et al., 2003). This fact was observed in this work, where baru explants submitted to BAP concentrations without ANA addition developed higher numbers of sprouts.

According to the results presented, observed that greater sprouting occurred in the absence of ANA. Similar results were observed by Vicente et al. (2009), when working with Vernonia condensata, found that concentration of $1.0 \mathrm{mg} \mathrm{L}^{-1} \mathrm{BAP}$ was the one that provided the best response to the number of sprouts per explant. Work with Jatropha curcas using $2.0 \mathrm{mg} \mathrm{L}^{-1}$ 6-benzylaminopurine (BAP) without presence of ANA showed greater multiplicity of buds and adventitious shoots (Lopes, 2012). These authors confirmed that the beneficial effect of BAP on sprout multiplication may be related to the influence of this regulator on cell division and on numbness breakdown of axillary yolks, until then inhibited by apical dominance (Brum et al., 2002).

Callus regeneration in Syzygium aromaticum using culture medium containing 2.4-D and BAP, positive interaction between auxin and cytokinin was observed, or when culture medium was used, no growth regulator was added (Jain et al., 2001). These authors observed different results from those found in this work, because the use of BAP without ANA in baru explants promoted higher number of sprouts from stem apexes. 


\section{Conclusions}

We concluded that foliar segments of Dipteryx alata in medium MS submitted to concentration of $3.0 \mathrm{mg} \mathrm{L}^{-1}$ BAP plus $2.0 \mathrm{mg} \mathrm{L}^{-1} \mathrm{ANA}$, was the most efficient for callus formation in relation to the evaluated concentrations.

There was no regeneration of callus formed from leaf explants when submitted to concentration of $2.0 \mathrm{mg} \mathrm{L}^{-1}$ BAP combined $0.5 \mathrm{mg} \mathrm{L}^{-1}$ ANA.

Cellular apices cultivated in MS medium using concentrations of 0.5 and $1.0 \mathrm{mg} \mathrm{L}^{-1} \mathrm{BAP}$ without addition of ANA and $1.5 \mathrm{mg} \mathrm{L}^{-1}$ combined with $0.1 \mathrm{mg} \mathrm{L}^{-1}$ ANA, were more efficient for the formation of $100 \%$ of callus in relation the evaluated concentrations.

Shoot apexes cultivated in MS medium using concentrations of 0.5 and $1.0 \mathrm{mg} \mathrm{L}^{-1}$ BAP without addition of ANA, was most efficient for formation of shoots from callus in relation the evaluated concentrations.

\section{References}

Alves, A. M., Mendonça, A. L., Caliari, M. E., \& Cardoso-Santiago, R. A. (2010). Avaliação química e física de componentes do baru (Dipteryx alata Vog.) para estudo da vida de prateleira. Pesquisa Agropecuária Tropical, 40(3), 266-273. https://doi.org/10.5216/pat.v40i3.6343

Brum, G. R., Silva, A. B., \& Pasqual, M. (2002). Efeito de diferentes concentrações de BAP e ANA na propagação in vitro da figueira (Ficus carica L.). Ciência Agrotécnica, 26(2), 1403-9.

Cassana, F. F., Pinto, L. S., Pohl, S., Bianchi, V. J., Braga, E. J. B., \& Peters, J. A. (2007). Regeneração de brotos a partir de folhas de Mirtilo cultivadas in vitro. Revista Brasileira de Biociências, 5(Supl. 2), 870-872.

Cordeiro, I. M. C. C., Lameira, O. A., Ohashi, S. T., \& Rosal, L. F. (2004). Efeito de BAP sobre a proliferação de brotos in vitro de Schizolobium amazonicum Huber ex Ducke (paricá). Cerne, 10(1), 118-124. https://doi.org/10.5902/198050985074

Dias, M. M., Pasqual, M., Araújo, A. G. de, Santos, V. A. dos, de Oliveira, A. C., \& Rodrigues, V. A. (2011). Concentrações de reguladores vegetais no estiolamento in vitro de ananás do campo. Semina: Ciências Agrárias, 32(2), 513-520. https://doi.org/10.5433/1679-0359.2011v32n2p513

Durigan, G., Melo, A. C. G., Max, J. C. M., Boas, O. V., Contieri, W. A. E., \& Ramos, V. S. (2011). Manual para recuperação da vegetação de Cerrado. Editora Páginas \&Letras, SMA, São Paulo.

Erig, A. C., \& Schuch, M. W. (2005). Regeneração in vitro de brotos e raízes adventícias de marmeleiro (Cydonia oblonga Mill.) cvs. MC e ADAMS, utilizados como porta-enxertos para a pereira. Revista Brasileira de Agrociência, 11(4), 419-424.

Flores, R. (2006). Cultura de tecidos e produção de B-ecdisona em Pfaffia glomerata e Pfaffia tuberosa (Amaranthaceae) (p. 168, Tese (Doutorado em Agronomia), Universidade Federal de Santa Maria, Santa Maria).

Flores, R., Maldaner, J., \& Nicoloso, F. T. (2006). Otimização da micropropagação de Pfaffia tuberosa (Spreng.) Hicken. Ciência Rural, 36(3), 845-51. https://doi.org/10.1590/S0103-84782006000300018

George, E. F., Hall, M. A., \& Klerk, G. J. (2008). Plant Propagation by Tissue Culture (3rd ed., p. 501). Dordrecht: The Background. https://doi.org/10.1007/978-1-4020-5005-3

Ikeuchi, M., Sugimoto, K., \& Iwase, A. (2013). Plantcallus: Mechanisms of induction and repression. The Plant Cell, 25, 3159-3173. https://doi.org/10.1105/tpc.113.116053

Jain, A., Kantia, A., \& Kothari, S. L. (2001). In vitro differentiation of shoot buds from leaf-callus of Dianthus caryophyllus L. and control of hiperhydricity. Scientia Horticulturae, 87(4), 319-326. https://doi.org/ 10.1016/S0304-4238(00)00185-0

Landa, F. S. L., Paiva, R., Paiva, P. D. O., \& Bueno Filho, J. S. (2000). Indução in vitro de calos em explantes foliares de pequizeiro (Caryocar brasiliense Camb.). Ciência e Agrotecnologia, 24, 56-63.

Larson, L. C. R. S. (2014). Estratégias de propagação de barueiro (Dipteryx alata Vog.) e jatobazeiro do cerrado (Hymenaea stigonocarpa Mart.) (124f., Tese (Doutorado), Universidade Estadual Paulista Júlio de Mesquita Filho, Faculdade de Engenharia de Ilha Solteira).

Lopes, L. C., Machado, I. S., Magoga, E. C., Andrade, J. G., Penna, H. C., \& Moraes, L. E. F. (2012). Cultura de embrião e indução de brotos in vitro para micropropagação do pinhão manso. Pesquisa Agropecuária Brasileira, Brasília, 47(7), 900-905. https://doi.org/10.1590/S0100-204X2012000700004 
Machado, I. S., Gomes, A. C., Bertozzo, F., Soriano, L., \& Arcalá, L. F. L. (2009). Indução de calogênese em meristemas de curauá in vitro. Revista Brasileira de Oleaginosas e Fibrosas, 13, 83-90.

Maciel, A. L. de R. (2001). Embriogênese somática indireta em Coffea arabica L. (p. 60, Dissertação (Mestrado em Fitotecnia), Universidade Federal de Lavras, Lavras, MG).

Mamedes, T., \& Araújo, S. (2010). Cultivo in vitro de explantes de Dipteryx alata (p. 10). Anais do VIII Seminário de Iniciação Científica e V Jornada de Pesquisa e Pós-Graduação Universidade Estadual de Goiás.

Morais, T. P., Luz, J. M. Q., Silva, S. M., Resende, R. F., \& Silva, A. S. (2012). Aplicações da cultura de tecidos em plantas medicinais. Rev. Bras. Pl. Med., 14(1), 110-121. https://doi.org/10.1590/S1516-0572201200 0100016

Murashige, T., \& Skoog, F. (1962). A revised medium for rapid growth and bioassay with tobacco tissue culture. Physiologia Plantarum, 15, 473-479. https://doi.org/10.1111/j.1399-3054.1962.tb08052.x

Nogueira, R. C., Paiva, R., Oliveira, L. M. D., Soares, G. D. A., Soares, F. P., Castro, A. H. F., Paiva, P. D. D. O. (2007). Indução de calos em explantes foliares de murici-pequeno. Ciência e Agrotecnologia, 31(2), $366-370$. https://doi.org/10.1590/S1413-70542007000200015

Paiva, R., \& Paiva, P. D. O. (2001). Textos acadêmicos: Cultura de tecidos. Lavras: FAEPE/UFLA.

Pasqual, M. (2001). Meios de cultura (p. 127). Lavras: FAEPE/UFLA.

Pérez-Tornero, O. P., Egea, J., Van Oostende, A., \& Burgos, L. (2000). Assessment of factors affecting adventitious shoot regeneration from in vitro cultured leaves of apricot. Plant Science, 158, 61-70. https://doi.org/10.1016/S0168-9452(00)00303-4

Pescador, R., Araújo, P. S., Maas, C. H., Rebelo, R. A., Giotto, C. R., Wendhausen Junior, R., ... Tavares, L. B. B. (2000). Biotecnologia da Piper hispinervium-pimenta longa. Biotecnologia, Ciência e Desenvolvimento, 3, 18-23.

Pinhal, F. H. (2012). Estabelecimento in vitro do Baruzeiro (Dipteryx alata Vog.) (63f., Dissertação (Mestrado), Universidade Federal de Uberlândia, MG).

Pozo, J. C. D., Lopez-Matas, M. A., Ramirez-Parra, E., \& Gutierrez, C. (2005). Hormonal control of the plant cell cycle. Biologia Plantarum, 123, 173-183. https://doi.org/10.1079/IVP2003436

Raghavan, V. (2003). One hundred years of zygotic embryo culture investigations. Vitro Cell. Dev. Biol. Plant, 39, 437-442. https://doi.org/10.1079/IVP2003436

Ratter, J. A., Bridgewater, S., Ribeiro, J. F., Dias, T. A. B., \& Silva, M. R. (2000). Estudo preliminar da distribuição das espécies lenhosas da fitofisionomia Cerrado sentido restrito nos estados compreendidos pelo Bioma Cerrado. Boletim do Herbário Ezechias Paulo Heringer, 5, 5-43.

Rezende, R. K. S., Scoton, A. M. N., Jesus, M., Pereira, Z. V., \& Pinto, F. (2019). Callus Induction in Baru (Dipteryx alata Vog.) Explants. Not Bot Horti Agrobo, 47(2), 538-543. https://doi.org/10.15835/nbha 47111366

Ribeiro, J. F., \& Walter, B. M. T. (2008). As principais fitofisionomias do Bioma Cerrado. In S. M. Sano, S. P. Almeida, \& J. F. Ribeiro (Eds.), Ecologia e flora (Vol. 1, pp. 152-212). Brasília: Embrapa.

Santos, A. C. P., Cordeiro, A. T., Campos, M. R. de C., Otoni, W. C., \& Zambolim, L. (2000). Calogênese em Coffea via cultura semi-sólida. Trabalho apresentado no Simpósio de Pesquisa dos Cafés do Brasil. Resumos expandidos (Vol. 2, p. 1490). Brasília, D.F.: Embrapa Café; Belo Horizonte: Minasplan. Retrieved from http://www.sbicafe.ufv.br/handle/123456789/564

Santos, B. R. (2004). Organogênese direta e indireta em calos e explantes foliares (p. 193, Tese de doutorado em fisiologia vegetal da UFLA, Lavras).

Santos, C. G., Paiva, R., Paiva, P. D. O., \& Paiva, E. (2003). Induction and biochemical analysis of callus obtained from leaf segments of Coffea arabica L., Cultivar Rubi. Ver. Ciência Agrotécnica, 27(3), 571-577. https://doi.org/10.1590/S0044-59672010000200005

Sousa, A. G. de O., Fernandes, A. G., Canuto, D., Alves, A. M., \& Freitas, J. B. (2011). Nutritional quality and protein value of the exotic almond of the Brazilian pineapple compared to the peanut. Food Research International, 44(7), 2319-2325. https://doi.org/10.1016/j.foodres.2011.02.013 
Sousa, G. A. A., Rondon, J. N., Cereda, M. P., Costa, F. A., Targa, V. M. I., \& Guilherme, D. O. (2019). Micropropagation of arrowroot (Maranta arundinacea). Agrarian Academic Journal, 2(1). https://doi.org/ 10.32406/v2n32019/10-16/agrariacad

Taiz, L., \& Zeiger, E. (2004). Fisiologia vegetal (p. 719). Porto Alegre: Artmed.

Torres, A. C., Caldas, L. S., \& Buso, J. A. (1998). Cultura de Tecidos e Transformação Genética de Plantas (Vol. 1, p. 509). Brasília, DF: EMBRAPA/CBAB.

Vicente, M. A. A., Almeida, W. A. B., \& Carvalho, Z. S. (2009). Multiplicação in vitro e aclimatação de Vernonia condensata Baker. Revista Brasileira de Plantas Medicinais, 11(2), 176-83. https://doi.org/10.1590/ S1516-05722009000200011

\section{Copyrights}

Copyright for this article is retained by the author(s), with first publication rights granted to the journal.

This is an open-access article distributed under the terms and conditions of the Creative Commons Attribution license (http://creativecommons.org/licenses/by/4.0/). 